McHargian LUSA in the Age of Non-Stationarity and Big Earth Observation Data

This article has been published in Social Ecological Practice Research Special Issue: “Design with Nature at 50: Retrospect and Prospect”. doi:https://doi.org/10.1007/s42532-019-00022-6. The copy edited version of this manuscript can be found here: https://link.springer.com/article/10.1007/s42532$\underline{019-00022-6}$

Suggested citation: Lim, T. Use of the McHargian LUSA in agricultural research and decision-making in the age of non-stationarity and big earth observation data. Socio Ecol Pract Res 1, 297-324 (2019). https://doi.org/10.1007/s42532-019-00022-6

\title{
Use of the McHargian LUSA in agricultural research and decision- making in the age of non-stationarity and big earth observation data
}

Theodore Lim, Assistant Professor, Urban Affairs and Planning, Virginia Tech, Blacksburg, VA 24060. tclim@vt.edu

\section{Abstract}

In the past fifty years, there have been two major changes that are of methodological and consequential importance to the McHargian land-use suitability analysis (LUSA): increasing evidence of nonstationarity of global and regional ecological conditions and increasing availability of high resolution spatial-temporal earth observation data. For fifty years, the McHargian LUSA has been an important analysis tool for designers and planners for both regional conservation planning and development. McHarg's LUSA is a decision support tool that reduces the dimensions of spatial-temporal data. This makes the technique relevant beyond decision support to spatial identification and prediction of areas of socio-ecological opportunity, risk, and priority. In this article, I use a set of recent studies relating to agricultural LUSA to reveal relationships between the traditional McHargian LUSA and related spatialtemporal research methods that are adapting to more data and non-stationary ecological conditions. Using a classification based on descriptive, predictive, and prescriptive research activities, I organize these related methods and illustrate how linkages between research activities can be used to assimilate more kinds of spatial "big data," address non-stationarity in socio-ecological systems, and suggest ways to enhance decision-making and collaboration between planners and other sciences.

Keywords: Land use suitability analysis, non-stationarity, big earth observation data, agriculture

\section{Introduction}

The land-use suitability analysis (LUSA), is a method popularized by Ian McHarg's seminal work, Design with Nature, originally published in 1969. McHarg's original LUSA, was a spatial overlay technique in which social and environmental variables of the region of interest were gathered and spatially mapped, classified by suitability for different land use types (e.g.: Residential, Conservation, Industrial, etc), then overlayed on each other, creating a composite map of suitability that could be used to support planning decision-making processes. The principle is that by gathering these layers and 


\section{McHargian LUSA in the Age of Non-Stationarity and Big Earth Observation Data}

organizing them into a composite map, better plans can be made and better outcomes achieved that meet both ecological and social values.

In Design with Nature, after introducing an example of a composite map produced through his overlay technique, McHarg pointed out "[the composite of the overlays] is not a plan. A plan includes the entire question of demand and the resolution of demand relative to supply, incorporating the capacity of the society or institution to realize its objective.” (McHarg 1969, p 105). In other words, the outcome or goal of the McHarg's LUSA was neither prediction nor prescription, but a rather, a rational, spatially explicit, and reproducible synthesis of the data from the socio-ecological due diligence and factgathering stages of the planning process. The McHargian LUSA can be thought of as a dimension reduction technique where multiple criteria, or 'dimensions' for the site, are combined to form one quantitative and descriptive summary of the study area. Inherent in the above quotation are two questions that are not addressed by the McHargian LUSA itself but are critical to spatial planning. The first question is that of demand - or the program that must be accommodated within the LUSAdescribed space. The second question is that of allocation - or the process by which conflicts due to space and programmatic limitations are resolved. These two questions-whose goals are predictive and prescriptive - are closely related to the descriptive power of the McHargian LUSA; They extend the fact-finding process to what may occur and what should occur in the study area in the future. While these two areas have not been a part of the traditional LUSA, they are major areas of socio-ecological research in the fields of land use modeling and spatial optimization, respectively.

In the decades following the publication of Design with Nature, there have also been two major changes that are of consequence to the LUSA that will be addressed in this study. First, of methodological importance, is the increase in the amount of geospatial data now more readily available for analysis ("big earth observation data", or BEOD). Second, of consequential importance, is the increasing evidence of spatial and temporal non-stationarity in global and regional ecological conditions. "Non-stationarity" refers to when an observed pattern, such as the mean or variability, in a given variable changes over space and/or time. Long-term climatological probabilities, for example, are now considered susceptible to non-stationary conditions because of climate change.

In this paper, I show how an expanded review of socio-ecological literature to include goals of prediction and prescription, in addition to the descriptions enabled by LUSA, illuminates opportunities for transdiciplinary collaboration, especially considering BEOD and non-stationarity. I use a literature review of Agricultural LUSA towards answering two questions:

1. How does the McHargian LUSA relate to other quantitative spatial-temporal land suitability methods, such as land use modeling and spatial optimization techniques?

2. How are big earth observation data (BEOD) and non-stationarity being incorporated into LUSA and related methods?

I selected the case of agriculture because of its relevance to LUSA, BEOD and non-stationary processes. First, like other land uses, there are many opportunities to incorporate values and knowledge into planning areas suitable for agriculture. Expert knowledge is frequently used in determining what criteria should be included in the LUSA, how criteria should be binned to represent suitability, and how 
the different criteria should be weighted against each other, based on importance. Second, agricultural land is susceptible to both development, and to abandonment, naturalization, and reforestation. The trade-offs in ecosystem services that result between land use decisions around agricultural land are therefore well-suited to LUSA (see, for example, McHarg, 2014, pp 181 -190 for his thinking on the susceptibility of agriculture and other ecosystem services on undevelopment land to fragmented suburbanization and Goldstein, et al., 2012, pp. 7568 - 7569 for analysis on different kinds of ecosystem service tradeoffs involving agriculture). Comparisons between agricultural locations to identify and prioritize key agricultural lands have been part of the US Department of Agriculture Land Evaluation and Site Assessment decision support system since the 1970s (more detail in the following section). Third, more so than other land use considerations, agricultural production is both a social and a biophysical process that is subject to non-stationary conditions and has been shown to incorporate feedback loops that affect subsequent suitability of land for agricultural use. The selection of one particular land use type narrowed the extent of the literature review and allowed for more focused illustration of examples.

\section{The relevance of BEOD and Non-stationarity to Agricultural Land Use Suitability}

The volume of BEOD readily available for public use has increased manifold since the first remote sensing programs were launched in the 1960s (Guo, Zhang, and Zhu 2015, p. 109). Much of the growth in BEOD has been driven by remotely sensed (RS) products collected through sensors mounted on orbital satellites. For example, in 2008, when NASA announced free, web-enabled access to data collected through the Landsat program, a civilian satellite program whose mission objective is to monitor and conduct scientific and exploratory studies of the Earth's surface, there were over 2 million images collected between 1972 - 2008 (Woodcock, et al. 2008, p. 1011). In 2015, there were over 5 million images in the USGS archive (Wulder et al. 2016, p. 282). NASA projects the volume of data stored and distributed through its Earth Observing System Data and Information System (EODIS) to accelerate through 2025, with the years between 2017 and 2022 having data ingestion rates projected to grow from 3.9 petabytes (PB) per year to as much as 47.7 PB per year, and by 2025, the volume of data in the EOSDIS archive is expected to be more than 246 PB. (https://earthdata.nasa.gov/about/eosdiscloud-evolution).

Table 1 shows examples of RS-derived data products, with currently available temporal coverages and spatial resolutions. In addition to raw BEOD, there are also a host of derivative products that are made and distributed. An example of a derivative product is the popular Normalized Difference Vegetation Index (NDVI), which is a calculated ratio using near infrared and red channels of multispectral imagery to represent vegetation density. Data products have also been developed into indexes for specific applications, such as monitoring urbanization, infrastructure, commodity stockpiles, agricultural productivity, and in emergency and disaster management and mitigation (UNGWG 2017, p. 18). 


\section{McHargian LUSA in the Age of Non-Stationarity and Big Earth Observation Data}

Table 1. Examples of RS data sources (adapted from Kerr and Ostrovsky 2003, p. 301)

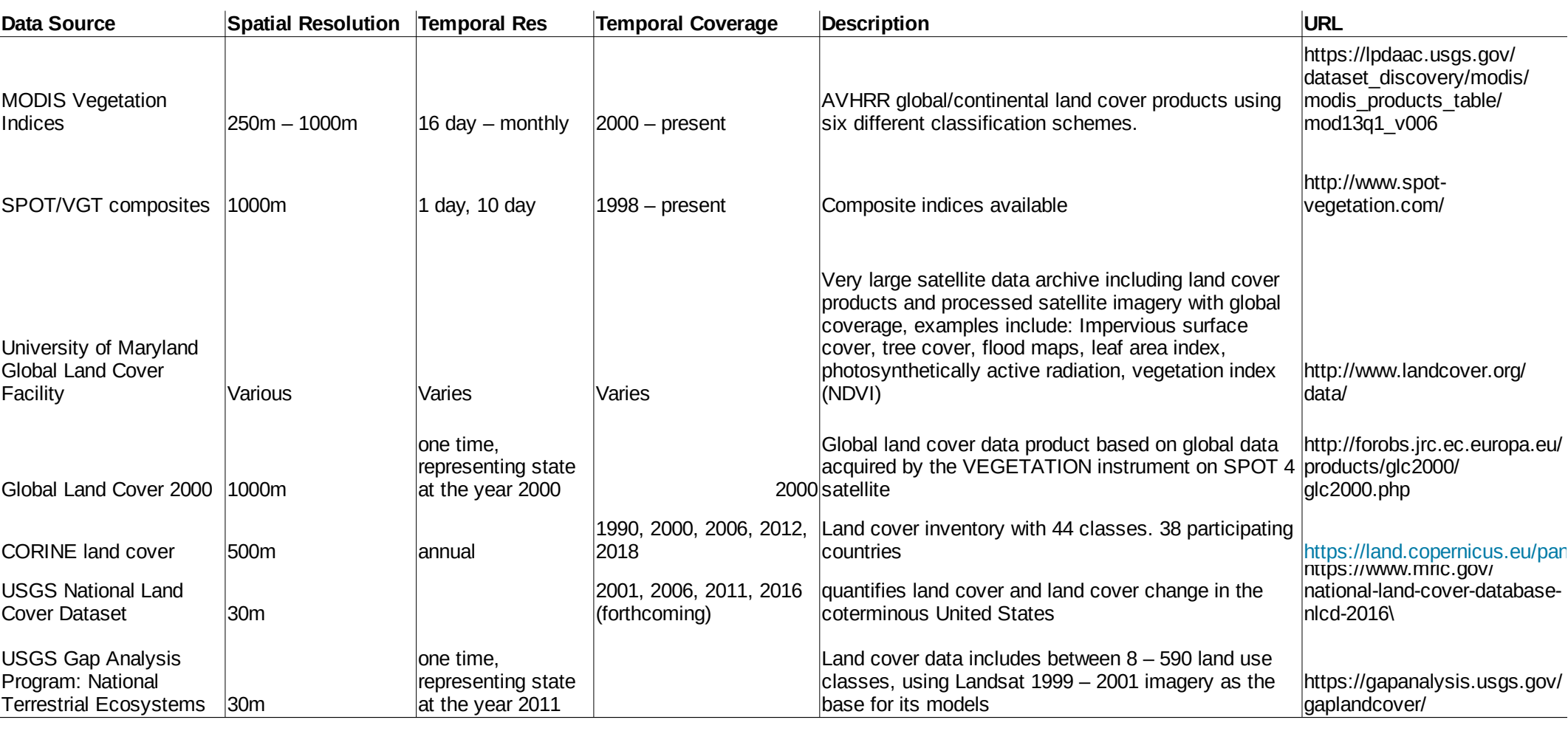

There has also been an increase in global interpolated datasets. Unlike RS data products, which are derived from data collected via satellite at global coverages, global interpolated datasets apply spatial interpolation techniques to data collected in specific locations on Earth in order to derive a continuous surface of values with global coverage. An example of this is the ISRIC-worldgrid for soil data (https:// www.isric.org/explore/soilgrids). The global ISRIC 250m resolution gridded dataset (SoilGrids250m) was created using machine learning algorithms trained on 150,000 soil profiles and remotely sensed soil covariates and is made available through an online interface or programmatically through REST APIs (Hengl et al. 2017, p. 3). Another example is WorldClim, a gridded high resolution $\left(1 \mathrm{~km}^{2}\right.$ resolution) monthly climate data source interpolated using data from up to 60,000 weather data stations (Fick and Hijmans 2017, p. 5).

Both RS data and interpolated data are usually stored and distributed in a raster-like format - where data is stored in an equally spaced grid array corresponding to the horizontal resolution of the data. This format is very amenable to incorporation into the type of Map Algebra weighted overlay technique that is at the core of the McHargian LUSA (Tomlin 1990).

Non-stationarity can either be spatial or temporal. Spatial non-stationarity refers to situations when a "global” representation of a phenomenon would fail to capture the localized structures within the study area (Fotheringham 2009, p. 398). Temporal non-stationarity refers to situations where conditions are changing over time. Climate change is one example of temporal non-stationarity, since past climate 


\section{McHargian LUSA in the Age of Non-Stationarity and Big Earth Observation Data}

patterns will not predict future climate patterns (Karl and Trenberth 2003, p. 1721). Social processes of technology diffusion result in spatial-temporal non-stationarity, since over time, both the locations and timing of these adoptions incorporate feedback-loops that make them dynamic and subject to larger patterns that emerge from individual behaviors.

The increase in BEOD and consideration of non-stationary conditions are particularly relevant when assessing agricultural land suitability. Handbooks summarizing environmental factors influencing productivity of common crops have been available for decades and are commonly used in assessing land capability globally (see, for example: FAO 1976; USDA 1961). Factors that are commonly considered include: climate, topography (e.g. slope and aspect), and soil fertility, as there is much evidence of the impact of these environmental variables on crop growth and yields. For example, in the US Midwest, where the highest global yields of corn and soybean are observed, soil properties have been found to explain $30 \%$ of yield variability, with soil organic matter explaining the most (Kravchenko and Bullock 2000, p. 79). The role of soils in evaluating agricultural productivity has been used in the land evaluation and site assessment (LESA) method adopted by the Soil Conservation Society (now the Natural Resources Conservation Service, NRCS) of the USDA since the 1980s. This program is discussed more in the following subsection. Interannual variability in crop production is explained by weather conditions faced during the growing season, which are linked to global long-term climatologies (Kellner and Niyogi 2015, p. 18). Global BEOD datasets such as WorldClim and SoilGrids250m can be useful in assessing land suitability for specific crops, especially in parts of the world where local datasets may be lacking. In the US, the amount of land in agricultural (cropland and pastureland) use collected by the USDA's Census of Agricultural is also complemented by its Natural Resources Conservation Service (NRCS) Natural Resources Inventory data product, which is based on remote sensing (USDA, 2018).

Non-stationarity stemming from climate change has been a major source of uncertainty for crop growth modeling, which is an important research activity for agricultural LUSA, because the prediction of how a crop will fare under future circumstances has major impacts on the long-term viability of this land use. The past 15 years has seen conflicting results of how increased atmospheric $\mathrm{CO}_{2}$ concentrations and warmer summertime temperatures might affect corn growth. There is much concern that climate change can result in increased droughts and flooding. Process-based models based on decades of field experiments on how plant physiology responds to heat unit accumulation vary in their predictions of outcomes of increased levels of atmospheric $\mathrm{CO}_{2}$, with some models foreseeing positive effects of warming and incrased $\mathrm{CO} 2$ for plant growty processes, and others predicting decreased yields.. Statistical-empirical evidence however tended to indicate that high temperatures would cause stress during key crop growth stages and therefore have very negative impacts on the yields of much of the world's grains and legumes (Schlenker and Roberts 2009, p. 15594; M. J. Roberts, Schlenker, and Eyer 2013, p. 236 ).

Agricultural productivity is not merely a function of environmental factors. Productivity is also highly dependent on technological adoption and land management practices, which are both social processes driven by market changes and technological diffusion dynamics within farming communities (Berger 2001, p. 247). Empirical research shows evidence of spatial differences in high yielding variety adoption by farmers (Griliches 1957, p. 501; Feder and Umali 1993, p. 215; A. D. Foster and Rosenzweig 1995, p. 1195), and management practices: crop rotation (Lockie et al. 1995, p. 61), 
McHargian LUSA in the Age of Non-Stationarity and Big Earth Observation Data

fertilizer application (Kassie et al. 2013, p. 536), and irrigation (Conley and Udry 2001, p. 668), for example. Proximity to markets and infrastructure can also affect the economic viability of agricultural land use (Fuglie and Kascak 2001, p. 386). Many of these studies highlight the processes of technological diffusion through information networks such as extension services or peer-to-peer social networks, indicating that technological adoption is not a function of static individual characteristics or social factors, but is a dynamic process influenced by neighbors and spatial proximity (Li, Wu, and Deng 2013, p. 632). In addition, global or local networked effects-- such as global trade practices and policies, social processes of technology diffusion, or proximity to reliable water delivery infrastructure-- might be imperceptible from BEOD datasets. Nevertheless, they remain important factors when assessing the viability of agricultural land use, especially under longer time ranges, when such temporal and spatial non-stationarity is likely to become more perceptible, and when past patterns are not as likely to be able to predict future patterns.

Another source of non-stationarity may come from agricultural practices themselves. Unsustainable agricultural practices can influence the long-term fertility of the land (L. Mueller et al. 2010, p. 604). Agricultural land use on steep slopes results in erosion from wind and water. Low yields may cause farmers to remove grass strips, hedgerows and shelterbelts to maximize field area, leading to higher rates of soil erosion. Crop intensification and the use of heavier machines can also damage the crop ecosystem (Pimentel et al. 1995, p. 1117), which can result in a feedback where increasingly marginal lands are developed for agriculture. Studies also demonstrate that crop intensification and increased irrigation in the US Midwest has induced changes to regional climate patterns. Increased evapotranspiration of highly yielding varieties of corn increases atmospheric water vapor, cooling temperatures that might otherwise result in crop-damaging heat extremes, an example of a positive feedback loop where crop intensification leads to more favorable conditions for crop growth (Lobell and Bonfils 2008, p. 2068; N. D. Mueller et al. 2016, p. 5).

\subsection{Agricultural Land Evaluation and Site Assessment (LESA)}

The focus of this paper on reviewing agricultural LUSA necessitates an explanation of the highly relevant and related decision-making tool, land evaluation and site assessment (LESA). The LESA method is a scoring system and decision support tool that was developed in 1971 by Lloyd E Wright (Steiner et al., 1994, pp. 32 - 34). While originally applied in to determine land values for tax purposes, it was later piloted by the USDA as a way to compare across agricultural properties to quantify how federal projects might influence the nation's supply of highly productive agricultural farmland. LESA is composed to two parts: (1) Land evaluation is the processes of identifying soil limitations and farmland ratings and involves experts such as conservationists, cooperative extension representatives, soil and water conservation district representatives, farmers, planners, local agricultural officials, and others with local land resources (Steiner et al., 1994, p. 35); (2) Site assessment is the process of scoring non-soil fertility related attributes of the land context, including: parcel size, on-farm investment, surrounding land uses, zoning ordinances, and other farmland protection policies or programs. Site assessment involves local officials or a locally-appointed site assessment committee (Steiner et al., 1994, p. 35).

Those opting to use the LESA decision support system can determine the points and weights allocated 


\section{McHargian LUSA in the Age of Non-Stationarity and Big Earth Observation Data}

to the land evaluation and site assessment portions of the analysis. This process of points and weights determination makes it highly related to the McHargian LUSA, though less emphasis is placed on the spatial overlay mapping part of the process than in traditional overlay analyses (for example of traditional LESA scoring, see Wright et al., 1983, p. 86). Although, some have also attempted to incorporate geospatial data for larger areas into the LESA framework using GIS (for example, see Dung and Sugumaran, 2005). The LE and SA portions of LESA, which each contain different criteria, can also be used separately (see Steiner et al., 1987 pp. 185 - 187 for example criteria in LE and SA). Since its original official adoption by the USDA in 1981, numerous local and state public agencies have used LESA to support land use decision-making processes (Coughlin et al., 1994, pp. 7 - 8). For example to protect against the threat of suburban sprawl and loss of agricultural lands, LESA criteria were incorporated into the Farmland Protection Policy Act (Steiner, et al., 1994, pp 43 - 54). Land trust and transfer/purchase of development rights (TDR/PRD) programs, which compensate farmers for lost potential revenue of foregone urban development in favor of continued agricultural use, use the LESA system to determine which lands should be retained for continued agricultural use and to prioritize TDR and PDR programs (Hoobler et al., 2003, p. 110) . Non-profit land trusts use the LESA method to prioritize strategic land acquisition (Hoobler et al., pp. 6-10). Like the traditional McHargian LUSA, LESA is used as an aid in decision-making, to reduce complex factors into a more comprehensible score that is reflective of the decision-makers' values.

To summarize, (1) BEOD has the potential to improve measurements of agriculturally-relevant conditions, (2) decisions about land use conversion between agricultural and other land use types (including urbanization and reforestation) are important and have long-term effects; and (3) decisions to develop agricultural land, maintain it in agricultural land use, or naturalize the land are in-part based on expectations and assumptions about non-stationarity, including changes in climate, such as frequency of droughts and floods, and broader social change.

\section{Methods}

In order to illustrate the range of goals and applications of the LUSA in agriculture, I conducted a systematic literature review. The objective of the literature review was to capture studies that utilize the McHargian overlay analysis to quantify agricultural suitability, but also to capture studies evaluating agricultural suitability using related methods. These methods have been mentioned by others, and include: participatory models, fuzzy logic, linear programming and optimization, cellular automata, and artificial intelligence and machine learning methods (Collins, Steiner, and Rushman 2001, p. 616; Malczewski 2004, Chapter 4). Because land use modeling, the prediction of land use of land cover change, often uses similar datasets to predict land use change as LUSA uses to assess suitability, I hoped to capture a representative slice of agricultural land use modeling in the literature review. Theoretically, there is a potential information feedback loop between LUSA and land use modeling, where the former identifies areas that are suitable for agriculture given input criteria, and the latter identifies which criteria have been important in explaining past agricultural land cultivation.

The selection of research articles was conducted through multiple queries through EbscoHost. Search terms included: "agriculture” or "agricultural” and each of the phrases "land use suitability," "land suitability," "land suitability analysis," and "land use suitability analysis.” The search terms were intentionally left sufficiently broad as to capture a range of methods related to traditional LUSA, 
including land use/land cover modeling. Articles were limited to publication within the 10-year period between 2009 - 2018 to reflect the current state of the art. Only articles in English, whose full-texts were available through the EbscoHost database, and which were published in peer-reviewed academic journals were included. A total of 93 unique articles were returned. Each article was screened for quality (comprehensibility in English, clarity of focus and methods) and relevance (land use suitability analysis-related, agricultural land use-related), leaving a total of 63 articles. It was not required that the included studies feature LUSA as the primary motivation of the study, therefore the study set also included research that used LUSA as an intermediate data processing step for other research objectives.

\subsection{Literature classification}

After selecting the articles to be reviewed, they were classified into categories. Past reviews have included classifications to organize the LUSA literature and illustrate trends in research methods. In 2001, Collins et al. traced the historical development of LUSA in the United States, describing six eras of the LUSA. The modern (post-computer-assisted overlay) areas were: the redefinition of spatial data and multicriteria evaluation, which included methods such as fuzzy set theory and multicriteria decision-making; the replication of expert knowledge, which included artificial intelligence tools; and the "new horizon" of land-use suitability techniques, including heuristic search process, expert systems, neurocomputing, and genetic programming (Collins, Steiner, and Rushman 2001, p. 616). Malczewski (2004, Chapter 4) categorized GIS-based LUSA into the following broad groups: computer-assisted overlay mapping, multicriteria evaluation methods, and artificial intelligence, or "soft computing or geocomputation” methods (including fuzzy logic, neural networks, evolutionary/genetic algorithms, and cellular automata techniques).

The above classifications are primarily based on methods. The classification used in this research focused instead on the purpose research activities included in each study. For each study included in the literature review, I made note of the presence of whether the study included goals of description, prediction, and/or prescription, where the following definitions were used to identify these goals:

- Description: A research activity whose goal is to summarize conditions in the area of interest for agricultural suitability. Multiple criteria, or dimensions, of the area of interest are considered and reduced into one composite map that describes the site. These studies include methods of dimension reduction or data aggregation that allow decision-makers to more easily comprehend and process sub-areas of opportunity, risk, or priority within the area of interest.

- Prediction: A research activity whose goal uses causal relationships of a particular phenomenon (e.g.: land use or land cover change) to project or simulate into the future what may occur under different or future circumstances (e.g. climate change). These studies may employ empirical-statistical, stochastic, optimization or dynamic simulation (e.g.: cellular automata, agent-based modeling, or physically-based models, such as biophysical crop growth models and physics-based hydrological models) (Lambin, Rounsevell, and Geist 2000, p. 325). They may be based on either deductive (theoretical) or inductive (empirical) logic (Overmars, et al., 2004, pp. 584 - 585). 
- Prescription: A research activity whose goal is to optimally allocate scarce resources (e.g. land) considering one or multiple potentially competing objectives (e.g. accommodating projected growth while minimizing environmental impacts).

Descriptive activities correspond closely to the original intent of the McHargian LUSA to gather the spatial socio-ecological dimensions of the site, organize them, and weight them according to their relevance to some proposed land use, reducing the site's multidimensionality to a highly relevant suitability index. The LESA process (see Section 2.1) similarly uses a scoring system that evaluates both soil-based agricultural productivity and other social-economic contextual factors in decisionmaking, reducing sites' multiple dimensions to a single comparative score. Prediction and prescription activities extend the descriptive process to what may occur and what should occur in the study area in the future given the objectives of the decision-makers. Others have used a similar framework to classify agricultural supply chain studies, referring to these goals as "levels of analysis" (Sharma, Kamble, and Gunasekaran 2018, p. 105). The classification used in this paper differs in its emphasis on goals of the activities rather than "levels" of analysis, and distinguishes description and prescription based on the presence of an explicit objective function and/or tradeoffs considered in the analysis.

In addition to noting research activities in each study according to this framework, I also made note of the use of BEOD and attention to issues of non-stationarity. BEOD was defined as the use of either RS data or globally interpolated datasets. Non-stationarity was considered "addressed" if the authors theorized about potential spatial-temporal feedbacks, locally-varying (not global) parameters, climate change, parameter uncertainty, or scenario planning and incorporated these theorized dynamics into their research methods.

\section{Results}

Of the 63 articles included in the literature review, $70 \%$ included descriptive research activity, 44\% included predictive research activity, and 6\% included prescriptive research activity. Figure 1 summarizes the number of articles including each research activity type. Table 2 summarizes all the studies included in the review, including presence of each research activity type, the motivations for each study, locations, decision makers included (especially in the determinations of criteria weights), the resolution of grids/units of analysis, and the geophysical and social criteria considered in the analysis. All but two studies included geophysical criteria or variables in their research activities. Thirty-three out of 63 studies included social criteria or variables. 
McHargian LUSA in the Age of Non-Stationarity and Big Earth Observation Data

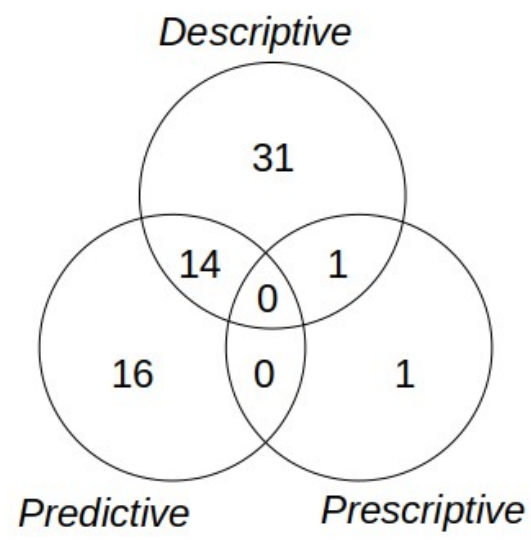

Figure 1.

Number of articles of each type published 


\section{McHargian LUSA in the Age of Non-Stationarity and Big Earth Observation Data}

\section{Table 2. Summary of studies included in review}

\begin{tabular}{|c|c|c|c|c|c|c|c|c|c|c|c|}
\hline Desc & Pred & Prescr & BEOD & $\begin{array}{l}\text { Non- } \\
\text { Station. }\end{array}$ & Motivation & Location & Decision-Makers & $\begin{array}{l}\text { Unit of } \\
\text { Anlaysis/Spatial } \\
\text { Resolution }\end{array}$ & Geo-physical criteria considered & Social criteria considered & Study \\
\hline $\mathrm{x}$ & & & & & Determine best land use types & Turkey & Not specified & map units & Soil, water & $\begin{array}{l}\text { Fertilizing practices, irrigation } \\
\text { scheduling }\end{array}$ & Dengiz et al., 2010 \\
\hline $\mathrm{x}$ & & & & & Integrated evaluation of coastal land use & Malaysia & 28 experts & $20 \mathrm{~m} \times 20 \mathrm{~m}$ & Proximity to geo-hazard risk areas & $\begin{array}{l}\text { Population density, transportation } \\
\text { access, public health access, beach } \\
\text { access, school access, proximity to life } \\
\text { support systems, proximity to high- } \\
\text { value areas, proximity to various } \\
\text { industries, existing plan }\end{array}$ & Pourebrahim et al., 2011 \\
\hline$x$ & & & & & $\begin{array}{l}\text { Identify less favored areas and biophysical } \\
\text { constraints }\end{array}$ & Lithuania & Experts & Not specified & Soil texture, soil drainage and terrain-slope & & Jarasiunas et al., 2017 \\
\hline $\mathrm{x}$ & & & & & $\begin{array}{l}\text { Develop geopedalogical approach to mapping } \\
\text { suitability }\end{array}$ & Iran & NA & Not specified & Soil, climate & & Roholla Mousavi et al., 2017 \\
\hline $\mathrm{x}$ & & & & & Identify areas suitable for citrus cultivation & Iran & $\begin{array}{l}30 \text { experts from the Iran } \\
\text { Citrus Research Institute }\end{array}$ & $80 \mathrm{~m} \times 80 \mathrm{~m}$ & $\begin{array}{l}\text { Climate, elevation, aspect, slope, water } \\
\text { resources }\end{array}$ & Roads network, population areas & Zabihi et al., 2015 \\
\hline$x$ & & & & & $\begin{array}{l}\text { Identify most important factors for saffron } \\
\text { cultivation in region, assess land }\end{array}$ & Iran & 20 local saffron experts & $100 \mathrm{~m} \times 100 \mathrm{~m}$ & Climate, soil, topography & & Maleki et al., 2017 \\
\hline $\mathrm{x}$ & & & & & Agricultural planning & Spain & $\begin{array}{l}\text { Various sources, though not } \\
\text { clear exactly how they were } \\
\text { incorporated }\end{array}$ & Cluster based & Natural environment & $\begin{array}{l}\text { Socioeconomic conditions, } \\
\text { infrastructure and legal framework } \\
\text { "objective information", "local experts } \\
\text { information", "ffarm information" }\end{array}$ & Cardín-Pedrosa et al., 2012 \\
\hline $\mathrm{x}$ & & & & & $\begin{array}{l}\text { Identify areas for forest conservation (for water } \\
\text { quality) through multi-criteria decision analysis }\end{array}$ & Brazil & $\begin{array}{l}\text { University professors, } \\
\text { researchers, landscape } \\
\text { ecologists, forest } \\
\text { hydrologists, } \\
\text { conservationists (21 total) }\end{array}$ & $30 \mathrm{~m} \times 30 \mathrm{~m}$ & $\begin{array}{l}\text { Land-use suitability (biogeophysical), soil } \\
\text { erodability, erosivity, proximity to roads, } \\
\text { proximity to surface water }\end{array}$ & & Vettorazzi and Valente, 2016 \\
\hline $\mathrm{x}$ & & & & & $\begin{array}{l}\text { Identifying areas "suitable" for agricultural land } \\
\text { use according to expert weights of input layers }\end{array}$ & Iran & $\begin{array}{l}\text { Agronomists and local } \\
\text { university faculty }\end{array}$ & $30 \mathrm{~m} \times 30 \mathrm{~m}$ & $\begin{array}{l}\text { Slope, aspect and elevation, soil depth, erosion } \\
\text { degree, land cover, groundwater levels }\end{array}$ & & Akinci et al., 2017 \\
\hline $\mathrm{x}$ & & & & & $\begin{array}{l}\text { Identifying areas "suitable" for agricultural land } \\
\text { use according to expert weights of input layers }\end{array}$ & Iran & $\begin{array}{l}\text { Agronomists and local } \\
\text { university faculty }\end{array}$ & $90 \mathrm{~m} \times 90 \mathrm{~m}$ & $\begin{array}{l}\text { Soil parameters, climatic data, topographic data, } \\
\text { land cover data }\end{array}$ & Land use & Kazemi and Akinci, 2018 \\
\hline $\mathrm{x}$ & & & & & Develop systematic evaluation of land quality & India & Experts & Not specified & Soil characteristics & & Chatterji et al., 2014 \\
\hline $\mathrm{x}$ & & & & & $\begin{array}{l}\text { Quantitative evaluation of local soil series } \\
\text { using different methods }\end{array}$ & India & $\begin{array}{l}\text { Participatory sessions with } \\
\text { local farmers }\end{array}$ & NA & Soil characteristics & & Vasu Duraisamy et al., 2018 \\
\hline $\mathrm{x}$ & & & & & $\begin{array}{l}\text { Identify criteria important to local farmers, } \\
\text { group learning }\end{array}$ & Ghana & Local participants & NA & Changes in precipitation & $\begin{array}{l}\text { Changes in subsidies, prices and } \\
\text { government credits }\end{array}$ & Badmos et al., 2014 \\
\hline $\mathrm{x}$ & & & & & Identify areas suitable for barley cultivation & Iran & Experts & Not specified & Slope, groundwater, soil characteristics & & Hamzeh et al., 2014 \\
\hline$x$ & & & & & $\begin{array}{l}\text { Identify areas suitable for jute and lentil } \\
\text { cultivation }\end{array}$ & India & 10 agronomy experts & Not specified & Soil characteristics & & Singha and Swain, 2018 \\
\hline$x$ & & & & & $\begin{array}{l}\text { Assessing land use suitability for agriculture } \\
\text { and grassland }\end{array}$ & Iran & Experts & Not specified & Physical, agronomic & Socio-economic & Memarbashi et al., 2016 \\
\hline $\mathrm{x}$ & & & & & Identify areas suitable for faba bean cultivation & ר Iran & Experts & Not specified & Soil, climate, topography & & Kazemi et al., 2016 \\
\hline$x$ & & & & & $\begin{array}{l}\text { Create agro-ecological zones identifying } \\
\text { candidate crop types }\end{array}$ & India & Experts & Not specified & Altitude, climate & & Sati and Wei, 2018 \\
\hline $\mathrm{x}$ & & & & & $\begin{array}{l}\text { Design indicators and reveal system } \\
\text { transitions in agro-ecology/farmland diversity }\end{array}$ & India & $\begin{array}{l}\text { Literature (Reidsma et al. } \\
\text { 2006) }\end{array}$ & NA & Biodiversity & & Amjath-Babu et al., 2015 \\
\hline $\mathrm{x}$ & & & & & $\begin{array}{l}\text { Identifying areas "suitable" for agricultural land } \\
\text { use according to expert weights of input layers }\end{array}$ & Turkey & $\begin{array}{l}\text { Local agronomists, local } \\
\text { university faculty members }\end{array}$ & $25 \mathrm{~m} \times 25 \mathrm{~m}$ & $\begin{array}{l}\text { Soil group, land use capability class, soil depth, } \\
\text { slope, elevation, erosion level and other soil } \\
\text { properties }\end{array}$ & & Akıncı et al., 2013 \\
\hline$x$ & & & & & $\begin{array}{l}\text { Identify areas of opportunity for a new cropping } \\
\text { system involving burclover }\end{array}$ & g United States & $\begin{array}{l}\text { Literature and farmers' } \\
\text { knowledge }\end{array}$ & $1 \mathrm{~km} \times 1 \mathrm{~km}$ & Soil, environmental and climate & & Mbũgwa et al., 2015 \\
\hline$x$ & & & & & $\begin{array}{l}\text { Other scoring methods cannot incorporate > } \\
10 \text { factors }\end{array}$ & United States & $\begin{array}{l}\text { Soil professionals and } \\
\text { previous agricultural land } \\
\text { suitability studies }\end{array}$ & $50 \mathrm{~m} \times 50 \mathrm{~m}$ & $\begin{array}{l}\text { Terrain, fertility, depth to water/bedrock, soil } \\
\text { density, climate, economics, accessibility, } \\
\text { management, topography, soil characteristics }\end{array}$ & & Montgomery et al., 2016 \\
\hline $\mathrm{x}$ & & & & & $\begin{array}{l}\text { Find sites for industry, taking into account } \\
\text { natural factors and excluding economic }\end{array}$ & Turkey & Seven experts & $5 \mathrm{~m} \times 5 \mathrm{~m}$ & $\begin{array}{l}\text { Wildlife development, protected areas, } \\
\text { vegetation, olive groves, pastures, agricultural } \\
\text { lanns, water, streams, land capability class, } \\
\text { slope, erosion }\end{array}$ & Settlement, transportation, & Aktaș et al., 2018 \\
\hline$x$ & & & & & not specified & Turkey & Not specified & map units & Soil characteristics & Agricultural profitability index & Killc, 2011 \\
\hline $\mathrm{x}$ & & & & & $\begin{array}{l}\text { Sensitivity analysis to layer } \\
\text { inclusion/exclusion }\end{array}$ & United States & Not specified & $\begin{array}{l}\text { polygons based on } \\
\text { cluster analysis }\end{array}$ & $\begin{array}{l}\text { Disturbance change, vegetation change, land } \\
\text { polygon size, cover type max patch size, cover } \\
\text { type total size }\end{array}$ & Land use condition, road density, & Humphries et al., 2010 \\
\hline$x$ & & & $x$ & & $\begin{array}{l}\text { Use farmers' existing knowledge as a starting } \\
\text { point for land evaluation criteria. }\end{array}$ & Jordan & Not specified & Not specified & Soil characteristics, precipitation, topography & & Ziadat and Sultan, 2011 \\
\hline $\mathrm{x}$ & & & $\mathrm{x}$ & & $\begin{array}{l}\text { Develop a web-based tool (Google Earth } \\
\text { Engine) to ingest global datasets for } \\
\text { agricultural suitability }\end{array}$ & Ethiopia & NA & varies & $\begin{array}{l}\text { Rivers/water bodies,soil characteristics, } \\
\text { elevation }\end{array}$ & Towns, land use & Yalew et al., 2016 \\
\hline$x$ & & & $x$ & & Identify areas suitable for shea cultivation & Sub-Saharan Africa & Experts & Not specified & $\begin{array}{l}\text { Temperature, precipitation, elevation, fire, } \\
\text { Nommalized Difference Vegetation Index (NDVI), } \\
\text { soil-type and soil-drainage }\end{array}$ & Land-use & Naughton et al., 2015 \\
\hline $\mathrm{x}$ & & & $\mathrm{x}$ & & Develop new land use plan & Bangladesh & $\begin{array}{l}5 \text { experts on Detailed Area } \\
\text { Plan }\end{array}$ & $300 \mathrm{~m} \times 300 \mathrm{~m}$ & $\begin{array}{l}\text { Existing land cover,elevation, distance to fault } \\
\text { line }\end{array}$ & $\begin{array}{l}\text { Utilities, proximity to transportation and } \\
\text { amenities }\end{array}$ & Ullah and Mansourian, 2016 \\
\hline $\mathrm{x}$ & & & $\mathrm{x}$ & & $\begin{array}{l}\text { Update suitable areas for oil palm (previous } \\
1969 \text { study's rainfall and water deficit have } \\
\text { changed) }\end{array}$ & Ghana & Experts & $1.1 \mathrm{~km} \times 1.1 \mathrm{~km}$ & Soil, climate, topography & & Rhebergen et al., 2016 \\
\hline
\end{tabular}




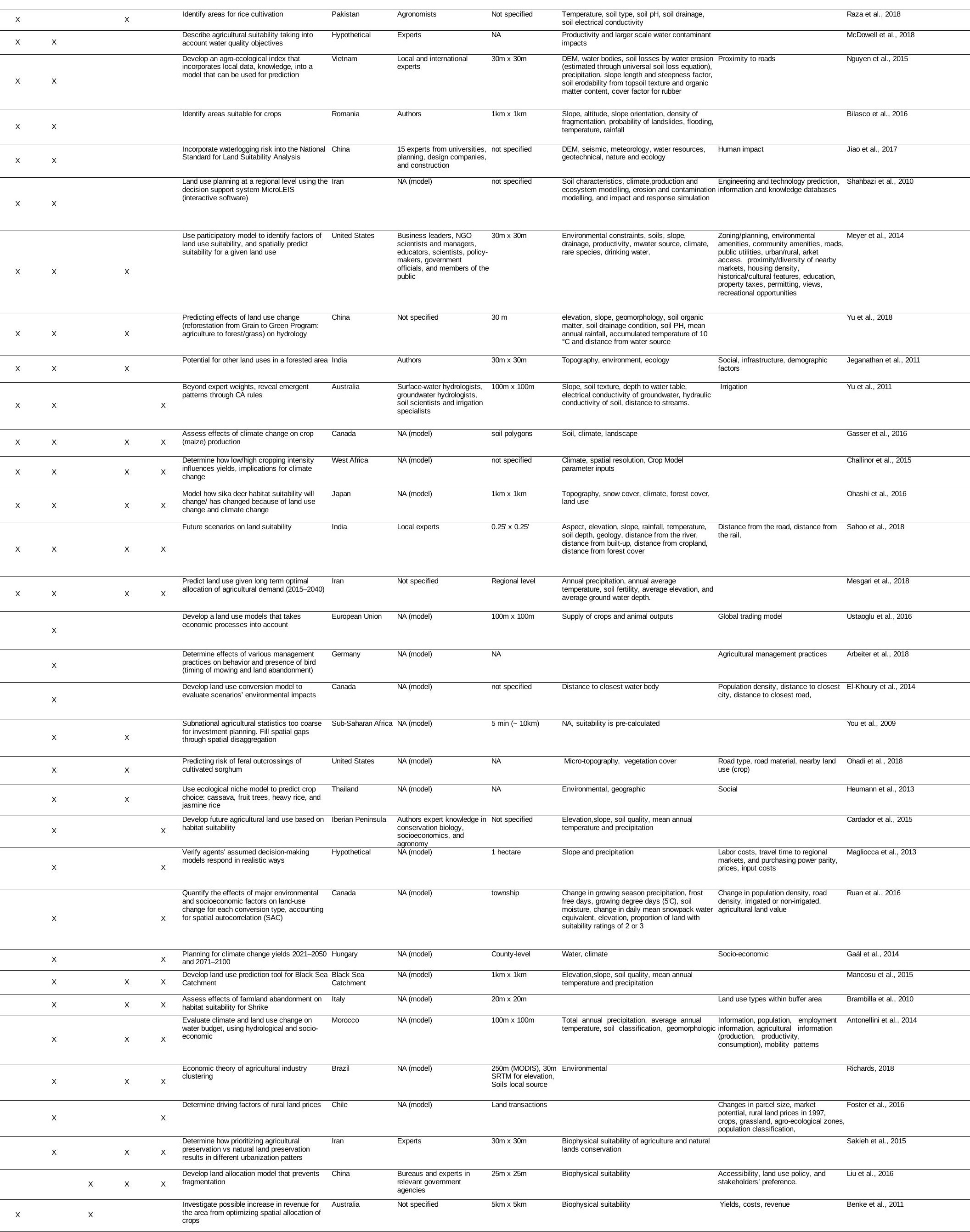


McHargian LUSA in the Age of Non-Stationarity and Big Earth Observation Data

The research activities were found to be associated with utilization of BEOD and consideration of nonstationarity. Table 3 summarizes whether BEOD was included or/and non-stationarity addressed by each type of research activity.

Table 3. Summary of articles considering non-stationarity and including BEOD, by type

\begin{tabular}{|c|c|c|c|c|}
\hline & \multicolumn{2}{|c|}{ NS considered } & \multicolumn{2}{|c|}{ NS not-considered } \\
\hline Type & BEOD $=$ Yes & BEOD $=$ No & BEOD $=$ Yes & BEOD $=$ NO \\
\hline Descriptive Only & 0 & 2 & 6 & 23 \\
\hline Some Predictive & 10 & 6 & 6 & 8 \\
\hline Some Prescriptive & 1 & 0 & 0 & 1 \\
\hline
\end{tabular}

BEOD was only used in 19\% of articles that only included descriptive activities (6 out of 31), while it was used in 53\% of those that had some predictive analysis (16 out of 30), and 50\% of those that had some prescriptive analysis (1 out of 2). Only 6\% of articles that only incorporated descriptive activities considered non-stationarity ( 2 out of 31 ), whereas $47 \%$ of those that had some predictive analysis in them did (14 out of 30 ), and 50\% of those that had prescriptive analysis did (1 out of 2). In the following sections, more detail is given to illustrate descriptive, predictive, and prescriptive research activities and their relationships to each other.

\subsection{Descriptive LUSA}

Studies that utilized descriptive methods only were the most numerous. Of the studies that incorporated descriptive activities, the majority employed a technique equivalent to McHarg's original weighted overlay method, a weighted sum of multiple criteria to form a spatially explicit composite map. These studies were often motivated to spatially identify lands suitable within a given study area to grow a specific crop. The motivation could be to explore the viability of introducing a new crop to a region, for example: shea trees in Africa (Naughton, Lovett, and Mihelcic 2015), saffron in Iran (Maleki et al. 2017), oil palm in Ghana (Rhebergen et al. 2016), or burclover in the United States (Mbũgwa, Prager, and Krall 2015). Criteria commonly used in the weighted sum analysis included: soil fertility characteristics, topography (elevation, slope, aspect), and climate variables, as is suggested by LUSA methods recommended by the FAO (1976) and USDA (1961). Acknowledging that economic viability of agricultural land use requires markets for products to be sold and infrastructure in transportation and production processes, several studies also consider socioeconomic conditions, infrastructure and legal frameworks (Cardín-Pedrosa and Alvarez-López 2012, p. 89; Pourebrahim, Hadipour, and Bin Mokhtar 2011, p. 87; Ullah and Mansourian 2016, p. 20; Memarbashi et al. 2017, p. 4; Humphries, Bourgeron, and Reynolds 2010, p. 229). Studies that included socioeconomic conditions were more likely to include suitability analyses for conservation land uses alongside agriculture land uses. These studies' incorporation of socioeconomic conditions are similar to the "site assessment" portion of LESA, which is used as a decision-making tool for prioritizing agricultural land conservation in the 


\section{McHargian LUSA in the Age of Non-Stationarity and Big Earth Observation Data}

face of development pressure, by considering both soil productivity and social factors in a weighting scheme.

Dimension reduction from multiple criteria to one composite suitability index is highly related to a large literature in agroecological zonation delineation, where methods range from matrix zonation (such as the Koppen climate classification) and unsupervised clustering techniques based on parameter space distance algorithms (van Wart et al. 2013). In crop suitability analyses, each criterion included is assigned a weight that reflect that criterion's importance to overall suitability. In the majority of the descriptive studies, these weights were determined by “experts” (agronomists, crop specialists, farmers, extension agents, the authors themselves) through methods such as fuzzy logic, the analytical hierarchal process (AHP) or the closely related Analytic Network Process (ANP). Although these methods are often referred to as "multicriteria decision-making" (MCDM) techniques, it should be noted that in the case of many of the crop suitability assessments, there are often no alternative land use decisions being considered-the 'decision' refers instead to a need to deduce the relative importance of physical factors under conditions of imperfect or missing knowledge of the "true" physical understanding of environmental controls on crop growth and yields. AHP allows experts to ensure the consistency of their weights through pairwise comparisons, and fuzzy logic explicitly acknowledges the gradients of transition in criteria assignments to better reflect human cognition in the layer aggregation process (e.g. Akıncl, Özalp, and Turgut 2013 p. 72; Montgomery et al. 2016, p. 341).

Another motivation for expert knowledge-driven weighting processes was to compensate for a dearth of locally-relevant data in the area of interest. For example, a study evaluating multiple crops in Jordan was motivated to start with local knowledge to inform the weighted sum of criteria because FAO-like suitability criteria typically do not take into account local management practices, such as irrigation. The omission of these practives resulted in large differences between on-the-ground conditions and the actual locations of agriculture and locations that appear to be "suitable" for agriculture based on FAO criteria (Ziadat and Sultan 2011, p. 288). The inclusion of local management practice criteria again, is similar to what might be considered in the site assessment portion of LESA.

Consideration of non-stationarity only occurred in two descriptive articles. In one, participation was elicited from local farmers to determine how changes in precipitation patterns and fluctuating market prices would change their choice of crop (Badmos et al. 2014, p. 19). In the other, socio-ecological feedbacks are incorporated into land suitability analyses related to intensification of agriculture in India (Amjath-Babu and Kaechele 2015, p. 174).

\subsection{Predictive activities and LUSA}

Following studies that utilized descriptive methods, the next most numerous were those that utilized predictive methods. Types of predictive models included both empirical-statistically based models and process-based models. Empirical-statistically-based models use independent (or “predictor”) variables (such as climate, topography, and soil type) to explain the variability in an observed target variable (or "predictand") (such as crop yields). Process-based models start with rules that are defined a priori to predict how the system will react under certain circumstances. Examples of this are agent-based and cellular automata models, where the rules of how a particular agent (a person, a tract of land, etc) might react (for example, change in state from rural to developed) are based on given transition probabilities 


\section{McHargian LUSA in the Age of Non-Stationarity and Big Earth Observation Data}

and neighboring agents' states; economic-based models where individuals or regions are expected to act according to theories of benefit maximization and economic rationality; and physics-based models. These two types of predictive models can be thought of as deductive (theory-based) or inductive (observation-based) (Overmars, Verburg, and Veldkamp 2007, p. 585). Table 4 shows the target variable (predictand) included in each study, the type of predictive model, and the method of evaluation (if evaluated) for the model.

As can be seen from Table 4, there was a wide range of uses of prediction in the agricultural LUSAs reviewed in this study, including: predictions of land use change, crop growth and yields, species observations (an indicator of habitat change), and physical phenomena, such as hydrological response or landslides. Of the 28 total studies that included predictive activities, half (14) were based on a priori assigned rules, derived from economic or behavioral theory or physical laws, and half (14) were based on empirical-statistical relationships uncovered by the studies themselves.

Model evaluation criteria among inductive predictive activities included the conventional statistical tests of goodness-of-fit (e.g.: AUC, $\mathrm{R}^{2}$, etc.), and only one study evaluated the effects of spatialtemporal stratification on their models (W. Foster et al. 2016, p. 657). Generalizability of conclusions drawn from study samples is especially an issue with empirical-statistical models because of the inherent temporal, spatial, hierarchical, and phylogenic structure within ecological data; it has been shown that traditional statistical methods, even those that use parametric methods to account for spatial autocorrelation and other structures among data points, tend to underestimate errors associated with spatial-temporal data. This is because in addition to non-independence of residuals, overfitting to the dependence structure of data can occur when models absorb variation to the 'wrong' predictor (D. R. Roberts et al. 2017, p. 915). Model evaluation techniques now commonly used with "big data" datasets, for example cross-validation techniques that use test and training sets for model fitting, do not usually take into account structured data typically found in models for spatial-temporal socioecological phenomena. While one reviewed paper included a discussion of spatial stratification based on agroecological zone, none of the papers reviewed implemented blocked cross-validation techniques to ensure properly estimated standard errors and generalizability to new predictive spaces (out-ofspace, out-of-time). One paper did explicitly specify prior distributions (Ohashi et al. 2016, p. 7767). Capturing uncertainty and the existence of sources of unmodeled structure is important for demonstrating a model's capability for making predictions for under non-stationary conditions: e.g.: future climate predictions. These are ongoing areas of socio-ecological research related to BEOD that were not found to be represented in the articles reviewed in this study. 


\section{McHargian LUSA in the Age of Non-Stationarity and Big Earth Observation Data}

\section{Table 4. Summary of articles including predictive activities}

\begin{tabular}{|c|c|c|c|c|}
\hline Predictand & $\begin{array}{l}\text { Model Approach } \\
\text { (deductive, } \\
\text { inductive) }\end{array}$ & Model Type & Model evaluation criteria & Study \\
\hline Daily streamflow & Deductive & Physical hydrology model & $\begin{array}{l}\text { Nash-Sutcliffe efficiency, coefficient of } \\
\text { determination, and percent bias }\end{array}$ & Yu et al. 2018 \\
\hline Contaminant source loads & Deductive & Physical contaminant transport model & None & McDowell et al., 2018 \\
\hline Land use change of a cell & Inductive & Stepwise logistic regression & AUC-ROC & Sahoo et al, 2018 \\
\hline Dry rubber yield & Deductive & Results of farmers' AHP weights & coefficient of determination (R2) & Nguyen et al., 2015 \\
\hline Crop production & Deductive & $\begin{array}{l}\text { Spatial allocation model (entropy approach) } \\
\text { Linear Programming using Net Present Value }\end{array}$ & coefficient of determination (R2) & You et al., 2009 \\
\hline Land use change of a cell & Deductive & method & None & Ustaoglu et al., 2016 \\
\hline Species presence, arrival departure, and detection & Inductive & Statistical (Markov Chain Monte Carlo) & F statistic & Arbeiter et al., 2018 \\
\hline $\begin{array}{l}\text { Land use change of a cell } \\
\text { Species observations (presence/absence) }\end{array}$ & $\begin{array}{l}\text { Deductive } \\
\text { Inductive }\end{array}$ & $\begin{array}{l}\text { Cellular automata with scenario-based rules } \\
\text { Statistical }\end{array}$ & $\begin{array}{l}\text { Kappa statistic, fuzzy Kappa, and Klocation. } \\
\text { AUC-ROC, specificity, sensitivity }\end{array}$ & $\begin{array}{l}\text { Mancosu, et al., } 2015 \\
\text { Carador et al, } 2015\end{array}$ \\
\hline Land use change of a cell & Deductive & Agent based model using economic theory & & Magliocca et al., 2013 \\
\hline Species observations (presence/absence) & Inductive & Logistic regression & AIC, AUC-ROC & Brambilla et al., 2010 \\
\hline Land use change of a cell & Inductive & $\begin{array}{l}\text { Statistical spatial autocorrelation model, } \\
\text { simple linear regression, spatial autoregressive } \\
\text { model, spatial error model }\end{array}$ & coefficient of determination and AIC & Ruan et al., 2016 \\
\hline & & Results from AHP used as rules for Cellular & & \\
\hline Land use change of a cell & Deductive & Automata & None & Yu et al., 2011 \\
\hline Hydrological water budget & Deductive & Catchment water balance model & None & Antonellini et al., 2014 \\
\hline Species observations (presence/absence) & Inductive & Logistic regression & Chi-square statistic & Ohadi et al., 2018 \\
\hline Land use change to agriculture in a cell & Inductive & Statistical (panel regression) & coefficient of determination (R2) & Richards, 2018 \\
\hline Farmers' crop choice & Inductive & MaxEnt model (machine learning) & AUC-ROC & Heumann et al., 2013 \\
\hline County yields & Inductive & Statistical regression & coefficient of determination (R2) & Gaal et al., 2014 \\
\hline Land use change of a cell & Inductive & CLUE model (logistic regression) & AUC-ROC & El-Khoury et al., 2014 \\
\hline Rural land prices & Inductive & $\begin{array}{l}\text { Statistical econometric method (instrumental } \\
\text { variables) }\end{array}$ & $\begin{array}{l}\text { coefficient of determination (R2), Root mean } \\
\text { squared error, F-test }\end{array}$ & Foster et al., 2016 \\
\hline & & $\begin{array}{l}\text { Future land scenarios based in suitability for } \\
\text { agriculture and conservation, within the } \\
\text { SLEUTH (cellular automata modeling) }\end{array}$ & & \\
\hline Land use change of a cell & Deductive & framework & & Sakieh et al., 2015 \\
\hline Occurence of a landslide & Inductive & Logistic regression & None & Blasco et al., 2016 \\
\hline Crop growth & Deductive & Biophysical crop growth model & None & Gasser et al., 2016 \\
\hline Waterlogging & Deductive & Hydrological model & None & Jiao et al., 2017 \\
\hline Crop yield & Deductive & Biophysical crop growth model & None & Challinor et al., 2015 \\
\hline Species observations (presence/absence) & Inductive & Logistic regression & Watanabe-Akaike Criteria & Ohashi et al., 2016 \\
\hline Erosion and soil leaching & Deductive & Physically based model & None & Shahbazi et al., 2010 \\
\hline Land use change of a cell & Inductive & CLUE model (logistic regression) & coefficient of determination (R2), standard error & Mesgari et al., 2018 \\
\hline Land use & Deductive & Programmatic rules to resolve conflcts & None & Jeganathan et al., 2011 \\
\hline Land use & Deductive & Rule based & None & Mesgari et al., 2016 \\
\hline
\end{tabular}

\section{* AUC-ROC = Area Under the Curve of the Receiver Operator Curve; AIC = Aikaike Information Criterion}

One reason cross-validation methods were not used in any of the studies may be for lack of data. Although $48 \%$ of studies that had predictive activities included the use of BEOD, predictands used in the studies usually represented relatively small data events. In empirically-based land use change models for example, land use change represents a small fraction of the overall dataset (most land uses remain unchanged between two points in time); in empirical habitat suitability models, RS data may be 
used to characterize environments, but the predictand is a much smaller and locally-collected species count data (Ohashi et al. 2016, p. 7765; Ohadi et al. 2018, p.3; Brambilla et al. 2010, p. 2272 - 2273 ; Arbeiter et al. 2018, p. 16). It is precisely under circumstances of data scarcity that violations of critical assumptions may make specious relationships appear stronger than they would be had the underlying structure of the data been considered in the statistical testing strategy (D. R. Roberts et al. 2017, p. 924).

Model evaluation criteria for deductive socio-ecological predictive activities were more frequently not discussed than for the inductive predictive activities in the literature reviewed. The lack of data for model calibration may be one reason that many deductive models did not report model evaluation criteria. The strength of deductive predictions is that they leverage existing theoretical knowledge on the processes affecting the dynamic being modeled. Theories have typically been accepted based on their applicability across a wide range of conditions and therefore may more successfully make predictions for a wide range of spatial-temporal conditions.

Parameters themselves may be highly uncertain in heterogeneous domains. Deductive predictive models may incorporate uncertainty into their predictions through explicitly specifying a wide distribution of values for input parameters. They may also examine uncertainty through sensitivity analysis, where input parameters are systematically perturbed to reflect a range of potential outcomes for future situations. In one land use/land cover change model reviewed, the authors test a range of values of a dispersion parameter around an expert-informed suitability function to assess sensitivity of the model to uncertain parameters (J. Yu et al. 2011, p. 138). In studies where non-stationarity due to climate change was considered, it was done through four main methods: (1) by varying the temperature and precipitation inputs to a model (either inductively or deductively specified), where the inputs were derived through regional downscaling of GCMs (Antonellini et al. 2014, p. 1842; Gaál, Quiroga, and Fernandez-Haddad 2014, p. 600; Gasser et al. 2016, p. 258); (2) the delta method downscaling of GCM predictions (Ohashi et al. 2016, p. 7768); (3) through the use of "storylines" corresponding to IPCC climate scenarios (Mancosu et al. 2015, p. 28; Cardador et al. 2015, p. 121); or (4) through sensitivity analysis (Challinor, Parkes, and Ramirez Villegas 2015, p. 1680).

Of the 29 studies that included predictive activities, 11 of them also included descriptive LUSA. The descriptive LUSA was used in two ways: (1) the descriptive LUSA was as a pre-processing step to the

predictive activity or (2) the predictive activity was used to create a criteria layer that was subsequently included in the descriptive LUSA. Where LUSA was a pre-processing step to the predictive activity, its function was to create likely scenarios for future development, which were then used to generate input parameters to the predictive model (D. Yu et al. 2018, p. 55). In cases where the predictive activity was used to create a criteria layer, that layer was then either represented as a continuous risk value in the descriptive LUSA (as in Bilaşco et al. 2016, p. 302), or recategorized using informed suitability thresholds (as in Jiao, Zhang, and Xu 2017, p. 102).

\subsection{Prescriptive activities and LUSA: Toward prescriptive processes}

In one sense, the ultimate goal towards which LUSA serves is a prescription of what land uses should 


\section{McHargian LUSA in the Age of Non-Stationarity and Big Earth Observation Data}

be implemented and where-- a plan, given the values of the stakeholders. In my classification of descriptive, predictive, and prescriptive goals, a "prescriptive" research activity is one that considers trade-offs in objectives, to suggest an optimal solution. In the present literature review, only two studies included prescriptive activities. Benke, Wyatt, and Sposito (2011, p. 93) used a genetic algorithm to allocate land for different kinds of crops maximizing the revenues that could be produced by that allocation. Only one study of those reviewed attempted optimization of multiple land uses using multiple criteria (Liu et al. 2016, pp. 3-5). This study considers maximization of economic benefit, ecological benefit, and social benefit, alongside stakeholder and expert knowledge to prevent land use fragmentation, as well as incorporate factors related to agricultural land operation, such as farming radius, and local agricultural land use policy. The allocation problem (how much, and where) is solved using particle swarm optimization, a heuristic method similar to other genetic algorithms.

Although prescriptive research activities were the least represented type given the search criteria for this review, the approach to prescribing "optimal” land use configurations given decision criteria is not uncommon. In his classification of GIS-based LUSA techniques, Malczewski (2004) discussed both linear optimization methods (p. 18), and evolutionary and genetic algorithms (pp. 40 - 42) that can search potential combinatory decision spaces in an effort to prescribe optimal solutions. Spatial optimization of land use for sustainability, for example, is an active area of research (see, for example: Cao, et al., 2011), that may not have appeared in this literature review because of my limitation to agricultural LUSA. It was also clear that among the studies reviewed, some had identified prescriptive goals as underlying motivations for their research that were not classified as "prescriptive" because they did not explicitly elaborate on the prescriptive research activity. For example, Meyer et al. (2014, p. 43) developed a stakeholder-driven spatial modeling framework so that the resulting composite LUSA map could be used to better handle conflicting demands of all stakeholders involved and sufficiently differentiated data for policy-makers to understand biophysical and socio-economic factors affecting land suitability. Here, the "prescription" for what land uses to adopt is arrived at through deliberation of stakeholder values. The contrast between prescriptive goals of the Liu et al. and Cao et al. flavor and the Meyer et al. flavor represents a fundamental difference in the role of technology in the creation of a 'prescription' for land use. The former represents a Spatial Experts System (SES), that aims to use artificial intelligence to imitate, extend, and replace the reasoning process of experts in solving spatial problems. The latter represents a Decision Support System (DSS), that uses artificial intelligence to support users in achieving a better decision. It emphasizes deliberation, communication, and collaboration as part of the decision-making process and creation of the "prescription."

\section{Discussion}

In this review of the literature of agricultural LUSA, I discussed the relationship between the traditional McHargian LUSA (descriptive LUSA), to related predictive and prescriptive spatial-temporal research activities. The majority of agricultural LUSA literature is descriptive in nature, with the goal of spatially identifying areas suitable for growing specific crops. This study was limited to agricultural land uses. This means that the specific application and examples, and the proportions of descriptive, predictive, and prescriptive research activities may not be generalizable to other land uses. However, many of the relationships between the research activities are likely to be generalizable. I found that studies that included LUSA did so to simplify the volume and diversity of socio-ecological data 


\section{McHargian LUSA in the Age of Non-Stationarity and Big Earth Observation Data}

representing a particular spatial problem, effectively reducing the multidimensionality of the site to a more easily comprehensible composite map.

In studies that incorporate both descriptive and predictive activities, the descriptive LUSA can be used as a dimension reduction technique to create future land use scenarios to predict other socio-ecological phenomena, or as a framework to organize the predictions of socio-ecological phenomena with other land suitability criteria. Among the studies reviewed, geophysical factors (such as climate and soil) were more likely to be included in the study than social factors (such as land use, infrastructure accessibility and demographic variables). Agricultural LUSA is highly related to the LESA method adopted by the USDA NRCD, which evaluated both soil productivity for agriculture and social factors for determining priorities between competing development decisions. The literature reviewed in this study showed that the land evaluation portion of LESA (based on soil productivity) is better represented than the site assessment portion of LESA. Scientific experts, which are also more associated with the land evaluation portion of LESA, were more represented than planners, politicians, economists, or citizens/residents as decision-makers in processes, who are often more associated with the site assessment portion of LESA.

According to the literature reviewed in this study, predictive research activity made it much more likely that LUSA research addressed issues of non-stationarity. This is because (1) addressing nonstationarity requires representation of emergent/dynamic phenomena and potentially high levels of uncertainty that can often not be represented by existing data layers, and (2) spatial-temporal nonstationarity can be better identified and quantified when using modeling techniques common to predictive activities. BEOD was also more likely to be used in research if the study included predictive or prescriptive activity than if the study only included descriptive activity. In fact, studies that included only descriptive activity were most likely to neither include the use of BEOD, nor address nonstationarity within the research, while studies that included some predictive activity were more likely to include both BEOD and non-stationarity than to include neither. However, despite the use of BEOD and advanced modeling techniques there was also evidence that predictive activities included in LUSA often did not report model evaluation criteria that accounted for temporal, spatial, hierarchical, or phylogenic structure, making it difficult to assess how models might generalize over an area being evaluated through descriptive LUSA. This is especially true because despite the use of BEOD in many studies, dependent variables included in studies were often based on local, not global "small data," including researcher-collected data such as species counts. While BEOD has certainly grown in coverage and resolution, many studies still rely on local data collection, especially for social criteria and variables, such as infrastructure service, local land uses, and demographic variables.

Lastly, the meaning of 'prescription' in the context of big data methods is dominated by application of quantitative optimization techniques. The meaning of 'prescription' could also be expanded from its conventional meaning to include the processes of arriving at "suitable" land use distributions that meet the complex requirements of diverse stakeholders. This expanded meaning would include: then facilitating communication processes, negotiation, trust, collaboration, and consensus building, which are familiar contexts for planners to engage with the prescription process. Although a comprehensive discussion of participatory modeling literature is outside the scope of this article, the ways in which LUSA intersect with descriptive, predictive, and prescriptive activities discussed above illustrate how the method can be used effectively as a "boundary object" facilitating communication among diverse 
stakeholders (Cash et al., 2003); as a tool for collaboratively designing scenarios that facilitate social learning, "bridging” and "stretching” (Xiang and Clarke, 2003; Pahl-Wostl et al., 2007); for visual communication (Arciniegas and Janssen, 2016); and for the iterative loops necessary when incorporating predictive modeled consequences of spatial or temporal non-stationarity (Voinov and Bousquet, 2009; Pourebrahim et al., 2011, Laniak et al., 2013; Grove et al., 2015). Figure 2 shows a conceptual diagram of how LUSA fits into the stages of a collaborative spatial decision-making process.

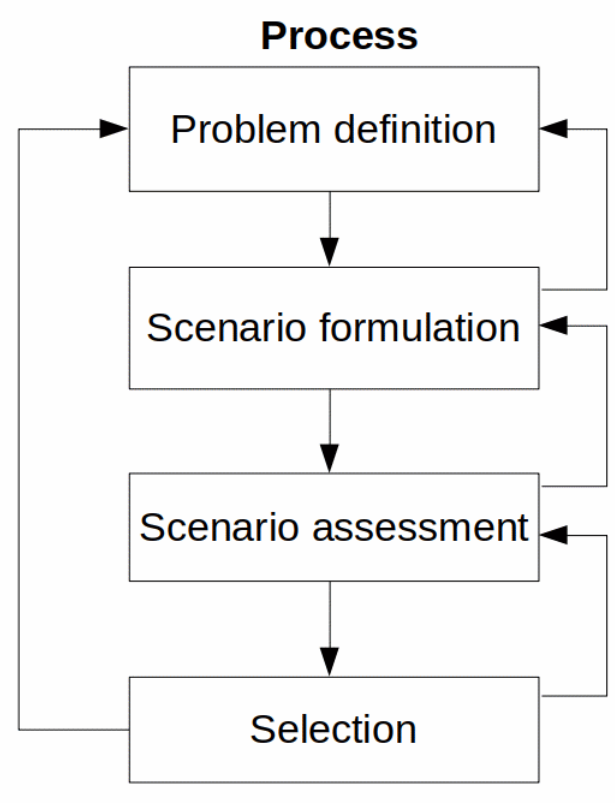

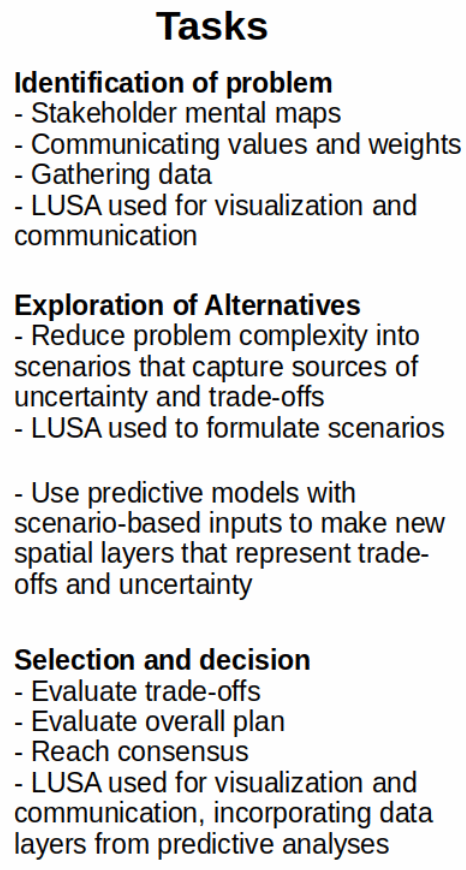

Tasks

Identification of problem

- Gathering data

- LUSA used for visualization and

communication

Exploration of Alternatives

uncertainty and trade-offs

- LUSA used to formulate scenarios

Use predictive models with scenario-based inputs to make new spatial layers that represent trade-

- Evaluate overall plan

- Reach consensus

communication, incorporating data

layers from predictive analyses

Figure 2. LUSA tasks within a collaborative spatial decision-making process (adapted from Arciniegas and Janssen, 2016)

\section{Conclusion}

This review of agricultural LUSA reveals areas of collaboration between planners and others involved in socio-ecological research. While the focus of McHarg's original LUSA was on historical and present socio-ecological patterns and mapping, today, consciousness of non-stationary conditions necessitate consideration about how long input criteria will represent reality and whether system dynamics could result in negative or positive feedback loops over time and space. This review suggests that outputs of predictive modeling represented as probabilities, risks, and future pressures specifically to capture uncertainty would be useful to incorporate within descriptive LUSA. Dynamic systems models that use 


\section{McHargian LUSA in the Age of Non-Stationarity and Big Earth Observation Data}

BEOD sources and methods to ensure generalizability and account for uncertainty are appropriate tools for addressing non-stationarity. LUSA likewise can be used to generate realistic hypothetical scenarios for predictive modeling to explore variability and sensitivity that incorporate decision-making and perspectives from diverse stakeholders.

\section{Conflict of Interest}

On behalf of all authors, the corresponding author states that there is no conflict of interest. 
McHargian LUSA in the Age of Non-Stationarity and Big Earth Observation Data

\section{References}

Akıncı, Halil, Ayşe Yavuz Özalp, and Bülent Turgut. 2013. “Agricultural Land Use Suitability Analysis Using GIS and AHP Technique.” Computers and Electronics in Agriculture 97 (September): 71-82. https://doi.org/10.1016/j.compag.2013.07.006.

Amjath-Babu, T.S., and Harald Kaechele. 2015. “Agricultural System Transitions in Selected Indian States: What Do the Related Indicators Say about the Underlying Biodiversity Changes and Economic Trade-Offs?” Ecological Indicators 57 (October): 171-81. https://doi.org/10.1016/j.ecolind.2015.04.029.

Antonellini, M., T. Dentinho, A. Khattabi, E. Masson, P. Mollema, V. Silva, and P. Silveira. 2014. “An Integrated Methodology to Assess Future Water Resources under Land Use and Climate Change: An Application to the Tahadart Drainage Basin (Morocco).” Environmental Earth Sciences 71 (4): 1839-53. https://doi.org/10.1007/s12665-013-2587-5.

Arbeiter, Susanne, Tobias Roth, Angela Helmecke, Hans Jochen Haferland, Franziska Tanneberger, and Jochen Bellebaum. 2018. “Conflict between Habitat Conservation and Corncrake Crex Crex Brood Protection in Managed Floodplain Meadows.” Agriculture, Ecosystems \& Environment 265 (October): 15-21. https://doi.org/10.1016/j.agee.2018.05.030.

Arciniegas, Gustavo, and Ron Janssen. 2012. "Spatial Decision Support for Collaborative Land Use Planning Workshops.” Landscape and Urban Planning 107 (3): 332-42.

https://doi.org/10.1016/j.landurbplan.2012.06.004.

Badmos, Biola K., Grace B. Villamor, Sampson K. Agodzo, and Samuel S. Guug. 2014. “Examining Agricultural Land-Use/Cover Change Options in Rural Northern Ghana: A Participatory Scenario Exploration Exercise Approach.” International Journal of Interdisciplinary Environmental Studies 8 (2): 15-35.

Benke, K. K., R. G. Wyatt, and V. A. Sposito. 2011. “A Discrete Simulation Approach to Spatial Allocation of Commodity Production for Revenue Optimisation over a Local Region.” Journal of Spatial Science 56 (1): 89-101. https://doi.org/10.1080/14498596.2011.567417.

Berger, Thomas. 2001. “Agent-Based Spatial Models Applied to Agriculture: A Simulation Tool for Technology Diffusion, Resource Use Changes and Policy Analysis.” Agricultural Economics 25 (2-3): 245-60. https://doi.org/10.1111/j.1574-0862.2001.tb00205.x.

Bilaşco, Ştefan, Sanda Roşca, Ioan Păcurar, Nicolaie Moldovan, Amalia Boţ, Cornel Negruşier, Paul Sestras, Mircea Bondrea, and Sanda Naş. 2016. "Identification of Land Suitability for Agricultural Use by Applying Morphometric and Risk Parameters Based on GIS Spatial Analysis.” Notulae Botanicae Horti Agrobotanici Cluj-Napoca 44 (1): 302-12. https://doi.org/10.15835/nbha44110289.

Brambilla, Mattia, Fabio Casale, Valentina Bergero, Giuseppe Bogliani, G. Matteo Crovetto, Riccardo Falco, Michaela Roati, and Irene Negri. 2010. “Glorious Past, Uncertain Present, Bad Future? Assessing Effects of Land-Use Changes on Habitat Suitability for a Threatened Farmland Bird Species.” Biological Conservation 143 (11): 2770-78.

https://doi.org/10.1016/j.biocon.2010.07.025.

Cash, David, William C. Clark, Frank Alcock, Nancy M. Dickson, Noelle Eckley, and Jill Jäger. 2002. "Salience, Credibility, Legitimacy and Boundaries: Linking Research, Assessment and Decision Making.” SSRN Scholarly Paper ID 372280. Rochester, NY: Social Science Research Network. https://papers.ssrn.com/abstract=372280. 
McHargian LUSA in the Age of Non-Stationarity and Big Earth Observation Data

Cao, Kai, Michael Batty, Bo Huang, Yan Liu, Le Yu, and Jiongfeng Chen. 2011. "Spatial MultiObjective Land Use Optimization: Extensions to the Non-Dominated Sorting Genetic Algorithm-II.” International Journal of Geographical Information Science 25 (12): 1949-69. https://doi.org/10.1080/13658816.2011.570269.

Cardador, Laura, Miquel De Cáceres, David Giralt, Gerard Bota, Núria Aquilué, Beatriz Arroyo, François Mougeot, et al. 2015. "Tools for Exploring Habitat Suitability for Steppe Birds under Land Use Change Scenarios.” Agriculture, Ecosystems \& Environment 200 (February): 119-25. https://doi.org/10.1016/j.agee.2014.11.013.

Cardín-Pedrosa, Marta, and Carlos José Alvarez-López. 2012. “Model for Decision-Making in Agricultural Production Planning.” Computers and Electronics in Agriculture 82 (March): 8795. https://doi.org/10.1016/j.compag.2011.12.004.

Challinor, Andrew J., Ben Parkes, and Julian Ramirez Villegas. 2015. "Crop Yield Response to Climate Change Varies with Cropping Intensity.” Global Change Biology 21 (4): 1679-88. https://doi.org/10.1111/gcb.12808.

Collins, Mg, Fr Steiner, and Mj Rushman. 2001. "Land-Use Suitability Analysis in the United States: Historical Development and Promising Technological Achievements.” ENVIRONMENTAL MANAGEMENT 28 (5): 611-21.

Conley, Timothy, and Christopher Udry. 2001. "Social Learning through Networks: The Adoption of New Agricultural Technologies in Ghana.” American Journal of Agricultural Economics 83 (3): 668-73.

Coughlin, Robert E., James R. Pease, Frederick Steiner, Lyssa Papazian, Joyce Ann Pressley, Adam Sussman, and John C. Leach. 1994. "The Status of State and Local LESA Programs.” Journal of Soil and Water Conservation 49 (1): 6-13.

Dung, E. J., and R. Sugumaran. 2005. "Development of an Agricultural Land Evaluation and Site Assessment (LESA) Decision Support Tool Using Remote Sensing and Geographic Information System.” Journal of Soil and Water Conservation 60 (5): 228-35.

El-Khoury, Antoun, Ousmane Seidou, David R. Lapen, Mark Sunohara, Que Zhenyang, Majid Mohammadian, and Bahram Daneshfar. 2014. "Prediction of Land-Use Conversions for Use in Watershed-Scale Hydrological Modeling: A Canadian Case Study Prévision de La Réaffectation Des Sols Pour La Modélisation Hydrologique Des Bassins Versants: Une Étude de Cas Canadienne.” Canadian Geographer 58 (4): 499-516. https://doi.org/10.1111/cag.12105.

FAO. 1976. A Framework for Land Evaluation. Rome, Italy: Food and Agriculture Organization. Feder, Gershon, and Dina L. Umali. 1993. “The Adoption of Agricultural Innovations: A Review.”

Technological Forecasting and Social Change, Special Issue Technology and Innovation In Agriculture and Natural Resources, 43 (3): 215-39. https://doi.org/10.1016/00401625(93)90053-A.

Fick, Stephen E., and Robert J. Hijmans. 2017. "WorldClim 2: New 1-Km Spatial Resolution Climate Surfaces for Global Land Areas: NEW CLIMATE SURFACES FOR GLOBAL LAND

AREAS.” International Journal of Climatology 37 (12): 4302-15. https://doi.org/10.1002/joc.5086.

Foster, Andrew D., and Mark R. Rosenzweig. 1995. "Learning by Doing and Learning from Others: Human Capital and Technical Change in Agriculture.” Journal of Political Economy 103 (6): 1176-1209. https://doi.org/10.1086/601447.

Foster, W., G. Anríquez, O. Melo, D. Yupanqui, and J. Ortega. 2016. “Geographic Disparities in Rural 
McHargian LUSA in the Age of Non-Stationarity and Big Earth Observation Data

Land Appreciation in a Transforming Economy: Chile, 1980 to 2007.” Land Use Policy 57 (November): 655-68. https://doi.org/10.1016/j.landusepol.2016.06.025.

Fotheringham, A. Stewart. 2009. “"The Problem of Spatial Autocorrelation’ and Local Spatial

Statistics: Spatial Autocorrelation and Local Spatial Statistics.” Geographical Analysis 41 (4):

398-403. https://doi.org/10.1111/j.1538-4632.2009.00767.x.

Fuglie, Keith O., and Catherine A. Kascak. 2001. "Adoption and Diffusion of Natural-Resource-

Conserving Agricultural Technology.” Applied Economic Perspectives and Policy 23 (2): 386-

403. https://doi.org/10.1111/1467-9353.00068.

Gaál, Márta, Sonia Quiroga, and Zaira Fernandez-Haddad. 2014. "Potential Impacts of Climate Change

on Agricultural Land Use Suitability of the Hungarian Counties.” Regional Environmental

Change 14 (2): 597-610. https://doi.org/10.1007/s10113-013-0518-3.

Gasser, P.-Y., C.a.s. Smith, J.a. Brierley, P.h. Schut, D. Neilsen, E.a. Kenney, and Yang. 2016. “The

Use of the Land Suitability Rating System to Assess Climate Change Impacts on Corn

Production in the Lower Fraser Valley of British Columbia.” Canadian Journal of Soil Science

96 (2): 256-69. https://doi.org/10.1139/cjss-2015-0108.

Goldstein, Joshua H., Giorgio Caldarone, Thomas Kaeo Duarte, Driss Ennaanay, Neil Hannahs,

Guillermo Mendoza, Stephen Polasky, Stacie Wolny, and Gretchen C. Daily. 2012. "Integrating Ecosystem-Service Tradeoffs into Land-Use Decisions.” Proceedings of the National Academy of Sciences 109 (19): 7565-70. https://doi.org/10.1073/pnas.1201040109.

Griliches, Zvi. 1957. "Hybrid Corn: An Exploration in the Economics of Technological Change.”

Econometrica 25 (4): 501-22. https://doi.org/10.2307/1905380.

Grove, J Morgan, Rinku Chowdhury, and Daniel L. Childers. 2015. “Co-Design, Co-Production, and

Dissemination of Social-Ecological Knowledge to Promote Sustainability and Resilience:

Urban Experiences from the U.S. Long Term Ecological Research (LTER) Network,” 6.

Guo, Hua-Dong, Li Zhang, and Lan-Wei Zhu. 2015. "Earth Observation Big Data for Climate Change

Research.” L 6 (2): 108-17. https://doi.org/10.1016/j.accre.2015.09.007.

Hengl, Tomislav, Jorge Mendes de Jesus, Gerard B. M. Heuvelink, Maria Ruiperez Gonzalez, Milan

Kilibarda, Aleksandar Blagotić, Wei Shangguan, et al. 2017. "SoilGrids250m: Global Gridded

Soil Information Based on Machine Learning.” PLOS ONE 12 (2): e0169748.

https://doi.org/10.1371/journal.pone.0169748.

Heumann, Benjamin W., Stephen J. Walsh, Ashton M. Verdery, Phillip M. McDaniel, and Ronald R.

Rindfuss. 2013. "Land Suitability Modeling Using a Geographic Socio-Environmental Niche-

Based Approach: A Case Study from Northeastern Thailand.” Annals of the Association of

American Geographers 103 (4): 764-84. https://doi.org/10.1080/00045608.2012.702479.

Hoobler, B. M., G. F. Vance, J. D. Hamerlinck, L. C. Munn, and J. A. Hayward. 2003. “Applications of Land Evaluation and Site Assessment (LESA) and a Geographic Information System (GIS) in

East Park County, Wyoming.” Journal of Soil and Water Conservation 58 (2): 105-12.

Humphries, Hope C., Patrick S. Bourgeron, and Keith M. Reynolds. 2010. "Sensitivity Analysis of

Land Unit Suitability for Conservation Using a Knowledge-Based System.” Environmental

Management 46 (2): 225-36. https://doi.org/10.1007/s00267-010-9520-4.

Jiao, Sheng, Xiaoling Zhang, and Ying Xu. 2017. “A Review of Chinese Land Suitability Assessment

from the Rainfall-Waterlogging Perspective: Evidence from the Su Yu Yuan Area.” Journal of

Cleaner Production 144 (February): 100-106. https://doi.org/10.1016/j.jclepro.2016.12.162.

Karl, Thomas R., and Kevin E. Trenberth. 2003. “Modern Global Climate Change.” Science 302

(5651): 1719-23. https://doi.org/10.1126/science.1090228. 
McHargian LUSA in the Age of Non-Stationarity and Big Earth Observation Data

Kassie, Menale, Moti Jaleta, Bekele Shiferaw, Frank Mmbando, and Mulugetta Mekuria. 2013. "Adoption of Interrelated Sustainable Agricultural Practices in Smallholder Systems: Evidence from Rural Tanzania.” Technological Forecasting and Social Change, Future-Oriented Technology Analysis, 80 (3): 525-40. https://doi.org/10.1016/j.techfore.2012.08.007.

Kellner, Olivia, and Dev Niyogi. 2015. "Climate Variability and the U.S. Corn Belt: ENSO and AO Episode-Dependent Hydroclimatic Feedbacks to Corn Production at Regional and Local Scales*.” Earth Interactions 19 (6): 1-32. https://doi.org/10.1175/EI-D-14-0031.1.

Kerr, Jeremy T., and Marsha Ostrovsky. 2003. "From Space to Species: Ecological Applications for Remote Sensing.” Trends in Ecology \& Evolution 18 (6): 299-305. https://doi.org/10.1016/S0169-5347(03)00071-5.

Kravchenko, Alexandra N., and Donald G. Bullock. 2000. "Correlation of Corn and Soybean Grain Yield with Topography and Soil Properties.” Agronomy Journal 92 (1): 75-83. https://doi.org/10.2134/agronj2000.92175x.

Lambin, E.F, M.D.A Rounsevell, and H.J Geist. 2000. “Are Agricultural Land-Use Models Able to Predict Changes in Land-Use Intensity?” Agriculture, Ecosystems \& Environment 82 (1-3): 321-31. https://doi.org/10.1016/S0167-8809(00)00235-8.

Laniak, Gerard F., Gabriel Olchin, Jonathan Goodall, Alexey Voinov, Mary Hill, Pierre Glynn, Gene Whelan, et al. 2013. "Integrated Environmental Modeling: A Vision and Roadmap for the Future.” Environmental Modelling \& Software, Thematic Issue on the Future of Integrated Modeling Science and Technology, 39 (January): 3-23.

https://doi.org/10.1016/j.envsoft.2012.09.006.

Li, Man, JunJie Wu, and Xiangzheng Deng. 2013. "Identifying Drivers of Land Use Change in China: A Spatial Multinomial Logit Model Analysis.” Land Economics 89 (4): 632-54. https://doi.org/ 10.3368/le.89.4.632.

Liu, Yaolin, Jinjin Peng, Limin Jiao, and Yanfang Liu. 2016. "PSOLA: A Heuristic Land-Use Allocation Model Using Patch-Level Operations and Knowledge-Informed Rules.” PLoS ONE 11 (6): 1-21. https://doi.org/10.1371/journal.pone.0157728.

Lobell, David B., and Céline Bonfils. 2008. “The Effect of Irrigation on Regional Temperatures: A Spatial and Temporal Analysis of Trends in California, 1934-2002.” Journal of Climate 21 (10): 2063-71. https://doi.org/10.1175/2007JCLI1755.1.

Lockie, Stewart, Ashley Mead, Frank Vanclay, and Brett Butler. 1995. "Factors Encouraging the Adoption of More Sustainable Crop Rotations in South-East Australia.” Journal of Sustainable Agriculture 6 (1): 61-79. https://doi.org/10.1300/J064v06n01_06.

Magliocca, Nicholas R., Daniel G. Brown, and Erle C. Ellis. 2013. "Exploring Agricultural Livelihood Transitions with an Agent-Based Virtual Laboratory: Global Forces to Local DecisionMaking.” PLoS ONE 8 (9): 1-11. https://doi.org/10.1371/journal.pone.0073241.

Malczewski, Jacek. 2004. “GIS-Based Land-Use Suitability Analysis: A Critical Overview.” Progress in Planning, 63.

Maleki, Fahimeh, Hossein Kazemi, Asieh Siahmarguee, and Behnam Kamkar. 2017. "Development of a Land Use Suitability Model for Saffron ( Crocus Sativus L.) Cultivation by Multi-Criteria Evaluation and Spatial Analysis.” Ecological Engineering 106 (September): 140-53. https://doi.org/10.1016/j.ecoleng.2017.05.050.

Mancosu, E., A. Gago-Silva, A. Barbosa, A. de Bono, E. Ivanov, A. Lehmann, and J. Fons. 2015. "Future Land-Use Change Scenarios for the Black Sea Catchment." Environmental Science \& Policy 46 (February): 26-36. https://doi.org/10.1016/j.envsci.2014.02.008. 
McHargian LUSA in the Age of Non-Stationarity and Big Earth Observation Data

Mbũgwa, Gatua wa, Steven D. Prager, and James M. Krall. 2015. "Utilization of Spatial Decision Support Systems Decision-Making in Dryland Agriculture: A Tifton Burclover Case Study.” Computers and Electronics in Agriculture 118 (October): 215-24. https://doi.org/10.1016/j.compag.2015.09.008.

McDowell, R.W., T. Snelder, S. Harris, L. Lilburne, S.T. Larned, M. Scarsbrook, A. Curtis, B. Holgate, J. Phillips, and K. Taylor. 2018. "The Land Use Suitability Concept: Introduction and an Application of the Concept to Inform Sustainable Productivity within Environmental Constraints.” Ecological Indicators 91 (August): 212-19. https://doi.org/10.1016/j.ecolind.2018.03.067.

McHarg, Ian. 1969. Design with Nature. Garden City, NY: Natural History Press.

McHarg, Ian L. 2014. “Open Space from Natural Processes.” In The Ecological Design and Planning Reader, edited by Forster O. Ndubisi, 181-90. Washington, DC: Island Press/Center for Resource Economics. https://doi.org/10.5822/978-1-61091-491-8 18.

Memarbashi, Elnaz, Hossein Azadi, Ali Barati, Fatemeh Mohajeri, Steven Passel, and Frank Witlox. 2017. "Land-Use Suitability in Northeast Iran: Application of AHP-GIS Hybrid Model.” ISPRS International Journal of Geo-Information 6 (12): 396. https://doi.org/10.3390/ijgi6120396.

Mesgari, Iman, and Mohammad Saeed Jabalameli. 2018. “An Integrated and Dynamic Approach to Agricultural Land use Change Modeling at Country level to Regional Scale: Application to Iran.” Systems Engineering 21 (1): 16-29. https://doi.org/10.1002/sys.21411.

Meyer, Spencer R., Michelle L. Johnson, Robert J. Lilieholm, and Christopher S. Cronan. 2014. "Development of a Stakeholder-Driven Spatial Modeling Framework for Strategic Landscape Planning Using Bayesian Networks across Two Urban-Rural Gradients in Maine, USA.” Ecological Modelling 291 (November): 42-57. https://doi.org/10.1016/j.ecolmodel.2014.06.023.

Montgomery, Bryn, Suzana Dragićević, Jozo Dujmović, and Margaret Schmidt. 2016. “A GIS-Based Logic Scoring of Preference Method for Evaluation of Land Capability and Suitability for Agriculture.” Computers and Electronics in Agriculture 124 (June): 340-53. https://doi.org/10.1016/j.compag.2016.04.013.

Mueller, Lothar, Uwe Schindler, Wilfried Mirschel, T. Graham Shepherd, Bruce C. Ball, Katharina Helming, Jutta Rogasik, Frank Eulenstein, and Hubert Wiggering. 2010. "Assessing the Productivity Function of Soils. A Review.” Agronomy for Sustainable Development 30 (3): 601-14. https://doi.org/10.1051/agro/2009057.

Mueller, Nathaniel D., Ethan E. Butler, Karen A. McKinnon, Andrew Rhines, Martin Tingley, N. Michele Holbrook, and Peter Huybers. 2016. "Cooling of US Midwest Summer Temperature Extremes from Cropland Intensification.” Nature Climate Change 6 (3): 317-22. https://doi.org/10.1038/nclimate2825.

Naughton, Colleen C., Peter N. Lovett, and James R. Mihelcic. 2015. "Land Suitability Modeling of Shea (Vitellaria Paradoxa) Distribution across Sub-Saharan Africa.” Applied Geography 58 (March): 217-27. https://doi.org/10.1016/j.apgeog.2015.02.007.

Nguyen, Thanh Tuan, Ann Verdoodt, Tran Van Y, Nele Delbecque, Thuy Chi Tran, and Eric Van Ranst. 2015. "Design of a GIS and Multi-Criteria Based Land Evaluation Procedure for Sustainable Land-Use Planning at the Regional Level.” Agriculture, Ecosystems \& Environment 200 (February): 1-11. https://doi.org/10.1016/j.agee.2014.10.015.

Ohadi, Sara, Matthew Littlejohn, Mohsen Mesgaran, William Rooney, and Muthukumar Bagavathiannan. 2018. "Surveying the Spatial Distribution of Feral Sorghum (Sorghum Bicolor 
McHargian LUSA in the Age of Non-Stationarity and Big Earth Observation Data

L.) and Its Sympatry with Johnsongrass (S. Halepense) in South Texas.” PLoS ONE 13 (4): 114. https://doi.org/10.1371/journal.pone.0195511.

Ohashi, Haruka, Yuji Kominami, Motoki Higa, Dai Koide, Katsuhiro Nakao, Ikutaro Tsuyama, Tetsuya Matsui, and Nobuyuki Tanaka. 2016. "Land Abandonment and Changes in Snow Cover Period Accelerate Range Expansions of Sika Deer.” Ecology and Evolution 6 (21): 7763-75. https://doi.org/10.1002/ece3.2514.

Overmars, Koen P., Peter H. Verburg, and Tom (A.) Veldkamp. 2007. “Comparison of a Deductive and an Inductive Approach to Specify Land Suitability in a Spatially Explicit Land Use Model.” Land Use Policy 24 (3): 584-99. https://doi.org/10.1016/j.landusepol.2005.09.008.

Pahl-Wostl, Claudia, M. Craps, A. Dewulf, E. Mostert, D. Tabara, and T. Taillieu. 2007. "Social Learning and Water Resources Management.” Ecology and Society 12 (2). http://repository.tudelft.nl/islandora/object/uuid:9bcb1311-74ac-4400-88e2-e6b816397dfd? collection=research.

Pimentel, D., C. Harvey, P. Resosudarmo, K. Sinclair, D. Kurz, M. McNair, S. Crist, et al. 1995. "Environmental and Economic Costs of Soil Erosion and Conservation Benefits." Science (New York, N.Y.) 267 (5201): 1117-23. https://doi.org/10.1126/science.267.5201.1117.

Pourebrahim, Sharareh, Mehrdad Hadipour, and Mazlin Bin Mokhtar. 2011. "Integration of Spatial Suitability Analysis for Land Use Planning in Coastal Areas; Case of Kuala Langat District, Selangor, Malaysia.” Landscape and Urban Planning 101 (1): 84-97. https://doi.org/10.1016/j.landurbplan.2011.01.007.

Rhebergen, Tiemen, Thomas Fairhurst, Shamie Zingore, Myles Fisher, Thomas Oberthür, and Anthony Whitbread. 2016. "Climate, Soil and Land-Use Based Land Suitability Evaluation for Oil Palm Production in Ghana.” European Journal of Agronomy 81 (November): 1-14. https://doi.org/10.1016/j.eja.2016.08.004.

Richards, Peter. 2018. “It’s Not Just Where You Farm; It’s Whether Your Neighbor Does Too: How Agglomeration Economies Are Shaping New Agricultural Landscapes.” Journal of Economic Geography 18 (1): 87-110.

Roberts, David R., Volker Bahn, Simone Ciuti, Mark S. Boyce, Jane Elith, Gurutzeta Guillera Arroita, Severin Hauenstein, et al. 2017. "Cross-Validation Strategies for Data with Temporal, Spatial, Hierarchical, or Phylogenetic Structure.” Ecography 40 (8): 913-29. https://doi.org/10.1111/ecog.02881.

Roberts, M. J., W. Schlenker, and J. Eyer. 2013. “Agronomic Weather Measures in Econometric Models of Crop Yield with Implications for Climate Change.” American Journal of Agricultural Economics 95 (2): 236-43. https://doi.org/10.1093/ajae/aas047.

Ruan, Xiaofeng, Feng Qiu, and Miles Dyck. 2016. “The Effects of Environmental and Socioeconomic Factors on Land-Use Changes: A Study of Alberta, Canada.” Environmental Monitoring \& Assessment 188 (8): 1-31. https://doi.org/10.1007/s10661-016-5450-9.

Sahoo, Satiprasad, Indrani Sil, Anirban Dhar, Anupam Debsarkar, Pulakesh Das, and Amlanjyoti Kar. 2018. "Future Scenarios of Land-Use Suitability Modeling for Agricultural Sustainability in a River Basin.” Journal of Cleaner Production 205 (December): 313-28. https://doi.org/10.1016/ j.jclepro.2018.09.099.

Sakieh, Yousef, Abdolrassoul Salmanmahiny, Javad Jafarnezhad, Azade Mehri, Hamidreza Kamyab, and Somayeh Galdavi. 2015. "Evaluating the Strategy of Decentralized Urban Land-Use Planning in a Developing Region.” Land Use Policy 48 (November): 534-51. https://doi.org/10.1016/j.landusepol.2015.07.004. 
McHargian LUSA in the Age of Non-Stationarity and Big Earth Observation Data

Schlenker, Wolfram, and Michael J. Roberts. 2009. "Nonlinear Temperature Effects Indicate Severe Damages to U.S. Crop Yields under Climate Change.” Proceedings of the National Academy of Sciences 106 (37): 15594-98. https://doi.org/10.1073/pnas.0906865106.

Shahbazi, Farzin, and Ali Asghar Jafarzadeh. 2010. "Integrated Assessment of Rural Lands for Sustainable Development Using MicroLEIS DSS in West Azerbaijan, Iran.” Geoderma 157 (34): 175-84. https://doi.org/10.1016/j.geoderma.2010.04.010.

Sharma, Rohit, Sachin S. Kamble, and Angappa Gunasekaran. 2018. "Big GIS Analytics Framework for Agriculture Supply Chains: A Literature Review Identifying the Current Trends and Future Perspectives.” Computers and Electronics in Agriculture 155 (December): 103-20. https://doi.org/10.1016/j.compag.2018.10.001.

Steiner, Frederick, Richard Dunford, and Nancy Dosdall. 1987. "The Use of the Agricultural Land Evaluation and Site Assessment System in the United States.” Landscape and Urban Planning 14 (January): 183-99. https://doi.org/10.1016/0169-2046(87)90028-4.

Steiner, Frederick R., James R. Pease, and Robert E. Coughlin, eds. 1994. A Decade With Lesa: The Evolution of Land Evaluation and Site Assessment. Ankeny, Iowa: Soil \& Water Conservation Society.

Tomlin, C. Dana. 1990. Geographic Information Systems and Cartographic Modeling. 526.0285 T659. Prentice Hall.

Ullah, Kazi Masel, and Ali Mansourian. 2016. "Evaluation of Land Suitability for Urban Land-Use Planning: Case Study Dhaka City.” Transactions in GIS 20 (1): 20-37. https://doi.org/10.1111/tgis.12137.

UNGWG. 2017. "Earth Observations for Official Statistics: Satellite Imagery and Geospatial Data Tast Team Report.” Queensland, Australia: United Nations Global Working Group.

U.S. Department of Agriculture. 1961. "Land Capability Classification.” Handbook 210. Washington DC: USDA Soil Conservation Service.

U.S. Department of Agriculture. 2018. Summary Report: 2015 National Resources Inventory, Natural Resources Conservation Service, Washington, DC, and Center for Survey Statistics and Methodology, Iowa State University, Ames, Iowa. http://www.nrcs.usda.gov/technical/nri/15summary

Ustaoglu, E., C. Perpiña Castillo, C. Jacobs-Crisioni, and C. Lavalle. 2016. "Economic Evaluation of Agricultural Land to Assess Land Use Changes.” Land Use Policy 56 (November): 125-46. https://doi.org/10.1016/j.landusepol.2016.04.020.

Voinov, Alexey, and Francois Bousquet. 2010. “Modelling with Stakeholders.” Environmental Modelling \& Software, Thematic Issue - Modelling with Stakeholders, 25 (11): 1268-81. https://doi.org/10.1016/j.envsoft.2010.03.007.

Wart, Justin van, Lenny G. J. van Bussel, Joost Wolf, Rachel Licker, Patricio Grassini, Andrew Nelson, Hendrik Boogaard, et al. 2013. "Use of Agro-Climatic Zones to Upscale Simulated Crop Yield Potential.” Field Crops Research, Crop Yield Gap Analysis - Rationale, Methods and Applications, 143 (March): 44-55. https://doi.org/10.1016/j.fcr.2012.11.023.

Wright, Lloyd E., Warren Zitzmann, Keith Young, and Richard Googins. 1983. "LESA—Agricultural Land Evaluation and Site Assessment.” Journal of Soil and Water Conservation 38 (2): 82-86.

Wulder, Michael A., Joanne C. White, Thomas R. Loveland, Curtis E. Woodcock, Alan S. Belward, Warren B. Cohen, Eugene A. Fosnight, Jerad Shaw, Jeffrey G. Masek, and David P. Roy. 2016. "The Global Landsat Archive: Status, Consolidation, and Direction.” Remote Sensing of Environment 185 (November): 271-83. https://doi.org/10.1016/j.rse.2015.11.032. 
Xiang, Wei-Ning, and Keith C Clarke. 2003. "The Use of Scenarios in Land-Use Planning.” Environment and Planning B: Planning and Design 30 (6): 885-909. https://doi.org/10.1068/b2945.

You, Liangzhi, Stanley Wood, and Ulrike Wood-Sichra. 2009. “Generating Plausible Crop Distribution Maps for Sub-Saharan Africa Using a Spatially Disaggregated Data Fusion and Optimization Approach.” Agricultural Systems 99 (2-3): 126-40. https://doi.org/10.1016/j.agsy.2008.11.003.

Yu, Dan, Ping Xie, Xiaohua Dong, Bob Su, Xiaonong Hu, Kai Wang, and Shijin Xu. 2018. “The Development of Land Use Planning Scenarios Based on Land Suitability and Its Influences on Eco-Hydrological Responses in the Upstream of the Huaihe River Basin.” Ecological Modelling 373 (April): 53-67. https://doi.org/10.1016/j.ecolmodel.2018.01.010.

Yu, Jia, Yun Chen, Jianping Wu, and Shahbaz Khan. 2011. "Cellular Automata-Based Spatial MultiCriteria Land Suitability Simulation for Irrigated Agriculture.” International Journal of Geographical Information Science 25 (1): 131-48. https://doi.org/10.1080/13658811003785571.

Ziadat, Feras M., and Kais A. Sultan. 2011. “Combining Current Land Use and Farmers' Knowledge to Design Land-Use Requirements and Improve Land Suitability Evaluation.” Renewable Agriculture and Food Systems 26 (04): 287-96. https://doi.org/10.1017/S1742170511000093. 